\title{
The Impact of East Asia's Nuclear Energy Development Program on Southeast Asia Countries
}

\author{
Mohamad Faisol Keling \\ College of Law, Government and International Studies \\ Universiti Utara Malaysia,06010, Sintok, Kedah, Malaysia \\ Tel: 60-4-928-6670 E-mail: m.faisol@uum.edu.my / teamcolgis@gmail.com.my \\ Otto F. Von Feigenblatt \\ Nova Southeastern University, Fort Lauderdale, Florida, USA \\ Tel: 561-860-0377Ｅ-mail: vonFeigenblatt@hotmail.com \\ Mohd Na'eim Ajis \\ College of Law, Government and International Studies \\ Universiti Utara Malaysia, 06010, Sintok, Kedah, Malaysia \\ Tel: 60-4-928-4249 E-mail: naeim@uum.edu.my / teamcolgis@gmail.com.my \\ Md. Shukri Shuib \\ College of Law, Government and International Studies \\ Universiti Utara Malaysia, 06010, Sintok, Kedah, Malaysia \\ Tel: 60-4-928-6668_E-mail:md.shukri@uum.edu.my / teamcolgis@gmail.com.my \\ Achmad Dzariean Mohd Nadzri \\ College of Law, Government and International Studies \\ Universiti Utara Malaysia, 06010, Sintok, Kedah, Malaysia \\ Tel: 60-4-926652 E-mail: achmad@uum.edu.my
}

\begin{abstract}
Commonly countries around the world view nuclear development in a negative light; that is threatening to national security. The nuclear disaster that happened on August 1945 in Japan, sacrificing over 200,000 lives and the explosion at Chernobyl nuclear plant in Ukraine on 26 April 1986 has drawn the attention of world community on the consequence of nuclear as energy resource (Ku Seman Ku Hussain, 2005). In actual fact, nuclear is an energy source providing positive impact to economic, politics and progress of a nation. Unfortunately, nuclear resources had been misconstrued and have become one of the factors that led Third World countries development process rate to lag behind developed countries. The spread of nuclear energy resources to Third World countries especially countries in the Asia-Pacific region at the moment is as a result of world community's awareness with interest and concern in developing nuclear energy as an alternative energy resource. The successful of several Develop Countries such as Japan and Third World countries such as South Korea, Brazil, India and Pakistan who have developed their own nuclear power have change the perception of the other Third World countries about the importance of nuclear power. This scenario brought effect and provides an opportunity to Malaysia to start paying attention on nuclear energy resource development.
\end{abstract}

Keywords: Nuclear Development, Nuclear Energy Resources, East Asia, Southeast Asia

\section{Introduction}

The application of nuclear energy source in Asia-Pacific especially East Asian countries is not a new issue in the area of nuclear development; on the other hand, it has generated development and rapid growth of efficient management usage of energy resource. What is interesting is that nuclear energy development have now grown, in fact the idea to own this alternative energy have spread throughout the region of Southeast Asia including 
Indonesia, Thailand and Myanmar. The change in development and ownership of this alternative energy source have influenced and motivated Malaysia's stance and perception on the usage of nuclear as an alternative energy resource. The rise and increase in fuel prices reaching USD150.00 (RM486.00) a barrel in July 2008 forced Malaysia to increase the oil price and reduce fuel subsidies of RM1.92 per liter to RM2.70 per liter in mid 2008. The increase in world oil price brought great burden to the Malaysian government and people. This world oil price phenomenon also influenced Malaysia to divert to nuclear energy as an alternative source. At the same time, the exponential of increase nuclear energy usage at regional level has as well persuaded the Malaysian government to establish opportunity to develop nuclear energy resources.

Nuclear energy is an energy resource that can be an alternative to countries around the world. When the world was facing energy source problem, nuclear energy becomes the focus and consideration of most countries to reduce their dependence on oil and gas. Uranium is nuclear's primary element that channels energy however it is one of the most difficult mineral resources to be found. Uranium have been discovered by Martin Heinrich Klaprorth a German scientist in year 1789, while in the same year Antoine Becquerel discovered that uranium has radioactive content. Nuclear is a source that can indeed revolutionize weaponry, energy and medical production. Whereas in a wider context, nuclear also can bring an immense effect on a country, involving political, economy and security aspects in general.

The interest in uranium is not only limited in the aspect of energy but also include economy, political and military aspects. This is because a powerful nuclear reactor of 1,000 Megawatt (MW) is capable of generating electric energy to a modern city with a population of one million people. Additionally, uranium can be produce into a nuclear weapon, providing mass effect in the area of military operation. This interest was clearly evident when the World War II in 1945 was terminated by just exploding two nuclear bombs directly on Hiroshima and Nagasaki destroying human lives and civilization with the effects of radiation remains until today. Interestingly, nuclear is no longer a new subject in Asia-Pacific, it has been widely discussed especially in generating internal energy source ensuring the development and catering to current need of a country. With are extensive nuclear awareness in Asia-Pacific and increase in world oil price crisis, it has surely influenced Malaysia to reassess its policy on nuclear energy development. Therefore, this article will analyze how the development of nuclear energy in the region has made Malaysia contemplate on building its own nuclear energy.

\section{The nuclear development in North-East Asia}

\subsection{Japan Nuclear Development}

The atomic bombing of two cities in Japan not only brought a profound physical and non physical effect on Japan but also to other countries in the East Asian region. This nuclear explosion on North-East Asia has additionally exploded the desire of countries in this region to possess its own nuclear energy. Japan as a nuclear bombing victim did not considered the human and civilization destruction in two of its towns as an obstacle in building nuclear energy (Perajurit, September 1999:28-30). Are we aware that Japan now owns more than 55 nuclear plants and is the third largest country in the world utilizing the benefit of nuclear to run its national energy? (Utusan Malaysia, 13 August 2004). Japan's desire to acquire its own nuclear energy was not a new issue; Japan was in fact the earliest Asian country to build nuclear power. Moreover, this idea to build nuclear energy was believed to be earlier compared to China who officially announced its possession of nuclear in 1964 . Japan's attempt of nuclear possession originated by the year end of 1940, it was based on Japanese Imperial 's military plan trying to create 'superbomb' through technology transfer cooperation with a German institute, the Institute of Physical and Chemical Research (Rikken) under Yoshio Nishina.

The objective to create super bomb also involve the Japanese Navy which named the project as "F-Go Project" allocated in Kyoto in 1942 and headed by Bunsaku Arakatsu. However the Japanese nuclear development efforts were disrupted when the United States attacked Japan in April 1945 (http://www.fas.org / nuke / guide / japan / nuke / index.html). The attack influenced Japan to move the research centre "heavy water" to Hungnam (a region in North Korea). Allegedly, the plan to create "heavy water" was detected by the enemy, Russia, who were defeated in the 1904-1905 War. The report of a nuclear development through Axis Power pact with the Germans was strengthened with the arrest of a U-234 German submarine by United States (US) in May 1945. The submarine arrest revealed 560 kilogram of uranium to be dispatched to Japan for the creation of the 'superbomb'. Japan attempt to build nuclear energy was again cut short when Hiroshima and Nagasaki were bombed in 6 and 9 August 1945. When Japan officially surrendered in 15 Ogos 1945, the United States found Japan's material to build nuclear. The bombing on Hiroshima and Nagasaki brought the Japanese nuclear development process to a stop; however it did not in anyway stop Japan's desire to possess nuclear power. The establishment of Japan's constitution after 1945 did nonetheless impede Japan to build its nuclear power when 
Japan constitution only allocated the defense expenditure not exceeding 1\% of Gross Domestic Product (Sakamoto,1988:83-84). This situation brought Japan in a crisis and dilemma of clash of interest especially in possessing nuclear and the sacrifice of civilization experienced during World War II.

After the war, Japan tried to change its identity as a military power to an identity which reflects Japan as an economic power. This change of identity does not mean that Japan abandon its desire to possess nuclear, on the other hand Japan still continue nuclear development for the purpose of energy preparation. In 1956, Japan took the step to structure a nuclear policy based on 3 nuclear principles called Japan's 3 Non-Nuclear Principle that banned the country to own or produce nuclear weapons or allow any nuclear weapon to entre Japan. The effort to development Japan's nuclear power was reactivated by the end of 1960 , especially when the then Prime Minister Japan, Eisaku Sato, on 5 February 1968 stressed that Japan would give the opportunity for nuclear development based on the 3 nuclear principles (http://www.fas.org / nuke / guide / japan / nuke / index.html accesses in August 2008). This Japanese nuclear policy framework was approved by Diet, the Japanese Parliament on the 24 November. The world economy and political situation in 1973 which witness the Arab countries sanctioning oil to the USA was an eye-opener and made Japan realize not to depend on energy source from others. In the early 1980s Japan started to pay attention on the energy source shortage problem especially in fulfilling domestic requirement. Thus this condition was what influenced Japan to develop nuclear for its own energy supply.

The Chernobyl nuclear disaster in Ukraine in 1986 that shook the world did not discourage Japan stance in continuing the nuclear development program. Even the explosion in Tokai-mura nuclear plant in March 1999 did not deterred Japan to stop its nuclear development (Utusan Malaysia, 17 December 1999). Japan nuclear development which started since the end of 1940s has put Japan on the same level with other nuclear superpowers particularly in the research technology area. Indeed, Japan is now recognized as an expert in nuclear technology and development. To date Japan has more than 55 nuclear plants providing more than $30 \%$ of energy source and is the third largest country in the world that utilizes nuclear energy after France and the USA (Hilmi Ismail, September 1999:4).

\subsection{China Nuclear Development}

China is among the world's nuclear superpower having veto power in the United Nations Security Council. The victory of the Chinese Communist Party (CCP) helmed by Mao Zedong in year 1949 has led China to emergence as a communist country. The "Red Book" approach demanded the county's development and struggle must go hand in hand with the military's power (Ibrahim Mohamed, December 2002:43-48). This approach influenced China to build up its own nuclear weapon ownership to fortify the communist struggle and assure China's national security as a whole. The nuclear explosion in Japan on 6 and 9 August 1945 showcasing the consequence of nuclear as weapon of destruction influenced China to develop its own nuclear energy. In the early stage of China's nuclear development, China requested help and nuclear technology from Russia, however this effort failed due to Russia's demand that China's military administration be placed under Russia, this is as condition to provide nuclear technology. This condition is impossible to submit thus causing China to find other alternative in developing its nuclear and military power (Voitti and Kauppi 1999: 69, Kien-hong Shark, 2000: 121-141).

China's success in testing its nuclear energy in Lop Nur on 16 October 1964 has made China surface as one of the world's nuclear superpowers. According to the report in SIRPRI's Yearbook 1999, until the year 1999 China has produce 400 nuclear warhead for its army, navy and air force (Mohd Zaki Mohd Salleh, November 2001:41-48). China has also developed and modernized its military force by employing up-to-date modern technology (You Ji, 1999). Thus far China has performed 44 nuclear weapon tests. Comparable to the nuclear development growth and USA's military aid to Japan, Taiwan and South Korea, China has taken the measures to enhance its nuclear development program, both to produce nuclear weapon or for energy supply (Hickey, 1996:153-170). On 7 April 2005, China has conveyed its intention and target a 15 years time frame for the development of nuclear power, whereby China forecast to own 40 nuclear plant to cater domestic need especially source of energy. In their short term plan, China targets to supply 20 million kilowatt of electricity in 2010 (Utusan Malaysia, 8 April 2005). This is corresponding to regional nuclear technology progress and the need of energy source to accommodate China's development. On the other hand, in their long term plan, China targets to 40 million kilowatt of electric for domestic use in 2020 (Utusan Malaysia, 8 April 2005).

\subsection{North Korea Nuclear Development}

The ballistic missile test carried out by North Korea in 4 July 2006 has shock the world with the speed of their Intercontinental Ballistic Missiles (ICBM) called Taepodong II enable to carry nuclear explosive to a distance of 
$5000 \mathrm{~km}$ (Ku Seman Ku Hussain, 25 Jun 2006). The intent of this test was meant to showcase Pyongyang's progress in nuclear and ballistics missile to rivals and the whole world in general. Since the USA has been labeling North Korea as a county of evil, Pyongyang's nuclear development is seen as the pretext to obtain the world's support to act against North Korea (Ramli Dollah, 2004: 107-124). North Korea has indeed set its place as one of the world's nuclear superpower when Pyongyang announced its success in creating nuclear weapon and intercontinental ballistics missiles in 1998. North Korea's nuclear development has started ever since the 1950s with the aid of other superpowers such as Russia and China. The pretext to provide energy was the reason to build nuclear power in North Korea. This country underwent war with South Korea in 1950-1953 decided to develop nuclear power as the main agenda of national defense to protect itself from external threats particularly the USA who has allocated their military in several locations in Northeast Asia such as South Korea, Japan and Taiwan (Barry, 2000:41). According to Mohd Zaki Mohd Salleh (2000:41):

"Behind the economic and poverty issues, Pyongyang remains confident in developing its military power, which does not only posses conventional capabilities but at the same time have increased nuclear and ballistics abilities."

In the attempt to achieve the objective in building nuclear power, Pyongyang made the energy problem as the alleged reason and ticket to build nuclear power (Bracken, 1995:56). In fact Pyongyang is believed to have a bigger agenda that is to develop nuclear weapons (Barry, 2000:47). On 14 December 1977, North Korea successfully built its first nuclear weapon and in 1987 Pyongyang accomplished in building its second nuclear reactor that has the ability to produce 7 kilogram of plutonium a year and have achieve in developing 1-2 nuclear weapon. Aware that Pyongyang is developing nuclear weapon, the USA proposed two nuclear plants powered by water to insist Pyongyang to stop their nuclear weapon development program in 1994 (Tae So, 1999:25; Mohd Zaki Mohd 2000:42). Until 1998, North Korea announced their biggest triumph in producing nuclear weapon and intercontinental ballistic missile Taepodong I (Wan Syawaludin Wan Hassan and Ramli Dollah, 2003: $55: 82)$

The emergence of nuclear power importance displayed by the USA in August 1945 through the bombing operation became a starting point of nuclear spreading around the world. Pyongyang's rapid nuclear development have caused security dilemma especially towards South Korea and the USA which went to war with North Korea. The North Korea and South Korea conflict has altered a new dimension in national security characterized by nuclear threat and conventional war (Scalapino, 1995: 183). It should be understood that the Korean War (1950-1953) is not entirely over, it is merely a cease fire signed on 27 July 1953. According to Mohd Zaki Mohd Salleh (2000:39):

"The war in Korea has never been declared ended, it was merely a s cease fire signed by Let Jen Nam-il and Let Jen William Harrison in Panmunjom on 27 July 1953."

\subsection{South Korea Nuclear Development}

South Korea supported by the USA received aid in terms of economy, military and nuclear technology (Kang Choi,1999:101-102). To date approximately more than 30,000 US military are sent to South Korea for 650,000 Seoul army to face Pyongyang's threat and 1.2 million army (Utusan Malaysia, 2006). Consistent with the importance of nuclear from security and economy pint of view, South Korea received nuclear technology from USA. In fact the nuclear development program of South Korea was activated since 1971 (Mohd Zaki Mohd Salleh, 2000:42). Due to energy shortage, in 1982 South Korea developed nuclear energy to supply energy and not nuclear weapon. The program received tremendous support from the USA by agreeing to channel nuclear technology to South Korea (Lin, 2000:105). In 2000, South Korea was reported producing fortified uranium that enables them to produce nuclear weapon. Consequently, the International Atomic Energy Agency (IAEA) went to investigate the development of nuclear weapon program in South Korea in November 2004. To date there are 20 nuclear power plants in South Korea (Utusan Malaysia, 4 April 2006).

\subsection{Taiwan Nuclear Development}

China's nuclear test on 16 October 1964 became a catalyst to Taiwan to consider developing nuclear power. At that moment Taiwan required the support and aid from USA in protecting their sovereignty and national security (Laster, 2000:184). The USA being very supportive towards Taiwan has made Taiwan an element in its interest in the region on East Asia (Copper, 1992:14). The US secretary of states, Dean Gooderham Acheson (1949-1953) once stressed the US's defense perimeter covers the whole of Japan to the Philippines (Bush, 1982:62):-

"... the US defense agenda in the region of Asia Pacific not only covers South Korea, but also deployed the troop to Japan and supplied the latest technology to Taiwan (Perajurit, December 2002:44).” 
Taiwan's history in facing crisis and tribulations with mainland China became the measurement in protecting national security (Saiful Anwar Md Ali, 2004:56, Newsweek September, 1995:10). Taiwan being threatened by regional nuclear development started research on nuclear power in Tsinghua National University in 1956. The first nuclear test conducted by China motivated Taiwan to develop its own water based nuclear power as the pioneer in discovering and building nuclear power. This program was also carried out to produce heavy water and research on plutonium which commenced in 1964. In September 1965 the Taiwan Research Reactor was build and started operating officially in the month of April 1973. With help from Canada, Taiwan successfully produced a nuclear reactor capable of generating 40 megawatt of electrical power. Taiwan rapidly increased research on nuclear especially concerning uranium. The biggest achievement of Taiwan was in the mid 1980s, whereby Taiwan owned six nuclear reactors utilizing the state-of-the-art technology with the capability to generate 4,900 megawatt of electricity. According to Kuang-ming Hsu (2000:184):-

"The ROC (Republic of Taiwan) has tried to develop its own nuclear weapons to act as a deterrent to the PRC's (People's Republic of China) eventual attack, but it has failed in the effort because of interference from international organizations."

Recently, the Taiwan cabinet known as Executive Yuan Council endorsed a new nuclear plant development costing RM21 million in 2001 (Utusan Malaysia, 1 February 2001). Until 2007, Taiwan has actively build two other nuclear reactors, making Taiwan possessing 8 nuclear plants (http://world-nuclear.org/info/inf115 taiwan.html)

\section{The Implication towards Malaysia and Southeast Asia Nuclear Development}

Indonesia being the country most hit by the hike of world oil price and after late president Sukarno's failure in developing nuclear power in 1965, announced their development of a nuclear power plant during the D-8 Summit in Bali on 13 May 2006. Indonesia's decision in building a nuclear plant in Muria, East Java with South Korea, Japan and France should be Malaysia's measurement in its attempt to build one. Referring to the Southeast Asian Nuclear Weapon Free Zone treaty (SEANWFZ) formed in 1995, this will not become an issue so long as the members do not develop nuclear power for the purpose on producing weapons. Myanmar, one of the poorest countries in the world, has already created their own mini nuclear reactor. Myanmar was linked to nuclear development when Myanmar provided sanctuary to two Pakistani scientists who fled to Myanmar after September 11 attacks in 2001 (Downs, 2003:38). China, Russia and North Korea are allegedly the countries responsible for providing nuclear technology and supporting Myanmar's nuclear program. Myanmar was rumored to have started developing nuclear power even before 2001, this is based on the national defense budget amounting to USD 9.239 billion in 1996 which made it the highest defense budget among the ASEAN countries and equaled to India's who is the greatest nuclear nation in South Asia (Downs, 2003:38). The issue of Myanmar's nuclear development was discussed in the East Asian Summit in Kuala Lumpur in December 2005. The awareness of nuclear energy source interest among Southeast Asia progressed when Vietnam in 2006 experienced energy crisis presented the proposal to build a nuclear reactor guarantee and secure production of energy. Until 2008, Vietnam was reported to actively build two nuclear plants with a power of $1000 \mathrm{MW}$ which is expected to operate in 2018 (Sarah Nadlim Rohim, 2008).

The increase in oil price to a staggering USD150.00 (RM480.00) per barrel in July 2008 witnessed the world to experience a phenomenal energy crisis. The effect on this oil crisis has threatened national security; hardening people's cost of living. The energy crisis forced countries to control subsidies and witness the people's protests. National security and political instability was also experienced by Malaysia when the people demanded the government to control the inflation of domestic products. The increase of world oil price has indeed challenge the government to find the best solution. To increase of domestic price up to RM0.70 a liter was the way out whereby at the same time, the government was forced to bear the actual cost of oil. The government realized the approach can only control in the short term because in reality the extinction of crude oil source will eventually influence the price of oil in the future.

The idea of possessing nuclear power is not novel to Malaysia, in fact this idea has been considered since 1957. According to a report in The Strait Times dated 21 August 1957 entitled A-bombs for Malaya explained that Malaysia will own atomic weapons when the British through the Anglo Malayan Defense Agreement ordered Australia to supply nuclear bombs to Malaysia in the intention to ward off the communist threat (The Strait Times, 21 August 1957). This course of history symbolizes the idea of owning nuclear is not foreign to Malaysia. This in no way means Malaysia wishes to produce nuclear for weapons, in contrary it is to provide source of energy to overcome the lack of world energy. This nuclear source of energy has been implemented by developed 
nations and now has spread to third world countries in the attempt to solve energy crisis and effectiveness in managing national economy.

On 27 November 2006, Malaysia explained that with the world oil price raising thus the government should not view nuclear energy as an inapplicable alternative or a far fetched choice. The government commitment to utilize nuclear was again mentioned by the minister of energy water and communication on 21 July 2008 (Utusan Malaysia, 22 July 2008). This is in unison with other nations in the world that has developed nuclear for effective and low cost energy source. The government's reaction in giving attention to the energy crisis is the starting point of the government to consider the possibility and national challenges in facing energy crisis in the future. The main concern is that the rise of oil will have a great impact on generating energy and would hinder Malaysia's effort in becoming a developed nation in 2020.

The director of Centre for Education Training and Research in renewable energy and energy efficiency (CETREE) USM, Prof Dr Kamarulazizi Ibrahim stated that it is time for Malaysian government to consider conducting research in nuclear energy utilization as energy source due to the shortage of today's energy source. It is alleged that Malaysia will be out of crude oil in a matter of 13 years and that gas will only last for 33 more years if the government does not find new well or source until 2009. The increase in oil price will increase electricity price which directly would affect foreign investments in the country. The rise in price would influence foreign investor to leave Malaysia and invest in other countries (Norliza Abas, 2005).

The dialogue on the importance of nuclear during the Islamic Science Academy Conference in Sarawak on 29 November 2003 exposed the danger of crude oil higher than nuclear energy. According to Dr. Samia Rashad from Egypt's National Nuclear Security and Radiation Control Center, a fossil generating station with a power of $1000 \mathrm{MW}$ releases 100 times more radioactive to the environment than a nuclear reactor. From an economical point of view, the gap between fossil fuels and nuclear is incredibly significant. To generate $1000 \mathrm{MW}$ fossil fuel in a year 2.6 million metric tones of charcoal or 2 million metric tones of oil. On the other hand, to generate the same amount of power, a nuclear reactor would only need 27 tones of oil a year (Zuhairi Ali, 2003). Nuclear significance is not only in the field of economy, it also helps the advancement of medicine. Developed countries have by now applied nuclear resource in the field of medicine. The risk of nuclear leakage can be overcome with systematic controlling and monitoring method. The latest technology and expert aid can be obtain from nuclear superpower like Japan, U.S, France and Germany, who are undeniably experienced and skillful in avoiding nuclear failure.

The Malaysian government statement during Asia Nuclear Collaboration Forum on 27 November 2006 proven that the government doe indeed have considered the importance of nuclear resource (Utusan Malaysia, 28 November 2006). Developing country should fully understand the need of nuclear as a source of energy that would assist a nation to progress. The success of developed countries such as U.S, Britain, France, Germany, Japan, China and others are the effort of systematical distribution of energy consumption. Which have led to increase in economy with lower cost and ensuring the availability of continuous energy resources. Therefore, nuclear resource is a resource that would guarantee development and fulfill the needs of a nation especially in providing energy resource. The governments decision to buy a nuclear reactor with a power of 20 megawatt announced by the Minister of Science, Technology and Innovation on 3 November 2006 brought a new leaf in the attempt to overcome energy shortage. With 66 local nuclear scientists, the mini reactor can be the pioneer in building a much more powerful nuclear reactor in this country in the future. The government's determination is clearly seen when the Malaysian Institute of Nuclear Technology was changed to Malaysian Nuclear Agency in September 2006 (Utusan Malaysia, 28 November 2006)

\section{Conclusion}

The nuclear bombings during World War II in Japan in August 1945 became the catalyst for nations across East Asia to possess their very own nuclear power. Mostly these countries commenced developing nuclear resource in the 1950s and 1960s. Strangely it did not depict their disappointment of the lives sacrificed and the destruction of civilization, in contrary East Asia somehow competed among each other to possess and develop this strategic energy resource. Through possession of nuclear resources, the development process of East Asia was moving rapidly. Moreover, the impact of this success has encouraged countries in the Southeast Asia to have economic cooperation and technology exchange. The strategic geographical location between Southeast Asia and East Asia has allowed the process of nuclear development to be given to Southeast Asia countries which intend to develop nuclear power.

The chronic global energy crisis in 2008, when petroleum resources has become limited, has brought to the increase of its high price. This has given a huge impact to the Southeast Asia countries which had caused the 
countries face security threats when the people in those countries made demonstrations to fight the ruling government. This scenario had influenced the Southeast Asia countries to find alternative ways by shifting to nuclear energy to solve the problem of being dependent on petroleum resources. China, Japan and South Korea's success in controlling its political and economic stability during global energy crisis is also another factor that influenced the Southeast Asia countries to develop nuclear energy. What's certain is that the success of nations in this region to cleverly plan and arrange economy progress based on this alternative energy resource is an example to follow and should make Malaysia responsive. With the unremitting instability of oil price it should motivate Malaysia to shift gear and develop nuclear energy without hesitant in the near future.

\section{References}

A dangerous game Taiwan: Lee walks a perilous line between Beijing and Washington. Newsweek.September 1995.

Bantah pembinaan markas baru tentera AS (Against on the construction of the new US military camp) . Utusan Malaysia.14 September 2006.

Barry M.P.(2000). America's role for peace on the Korean Peninsula. The Korean Journal of Defense Analysis. Vol. XII.No.I

Bracken P.(1995). Risk and promise in the two Korea's.Orbis.Vol.39.No.1

Buss, C. A. (1982). The United States and the Republic of Korea: Background of policy. Stanford University: Hoover Institution Press.

China mahu bina 40 loji nuclear (China wants build 40 nuclear lodge). Utusan Malaysia. 8 April 2005

Copper,J.F.(1992).China diplomacy, The Washington-Taipei-Beijing triangle. Oxford:Westview Press.

Downs F.(2003). Myanmar and North Korea: Birds of a feather? Asia Pacific Defence Reporter. October.

Hickey, D. V. (1998). Taiwan's security in the changing international system. London: Lynne Rienner Publishers Inc.

Hilmi Ismail.(1999). Perang untuk keamanan? (War for freedom?). Perajurit. September.

Ibrahim Mohamed.(2002). Budaya strategik dan dasar pertahanan maritim China(The policy of China maritime defence and strategic culture). Perajurit. December.

Jepun arah periksa loji nuklear (Japan ordered to inspect nuclear lodge). Utusan Malaysia.13 Ogos 2004.

Ji,Y.(1999).The armed forces of China. Sydney:Allen \& Unwin.

Kang Choi (1999). Strategic culture in the Asia Pacific Region, Korean: A tradition of peace and danger of war. New York: Macmillan Press Ltd.

Kim Tae-Seo (1999). An unexpected exchanged: North Korea's NLL provocation. East Asia Review. Vol.11. No.3. Diakses pada 1 Ogos 2008 daripada http://www.ieas.or.kr/vol11_3/kimtaeseo.htm

Ku Seman Ku Hussain (2006). Dunia diancam nuklear (The world threats by nuclear). Utusan Malaysia. 25 Jun.

Kuang ming-Hsu (2000).Taipei's national military strategies and policies. Dalam Martin L. Laster dan Peter Kien-hong Yu (pnyt). Taiwan's security in the post-Deng Xiaoping era. London:FrankCass\&Co Ltd.

Laster M.L. (2000). Theater missile defense and Taiwan's security. Dalam Martin L. Laster dan Peter Kien-hong $\mathrm{Yu}$ (pnyt). Taiwan's security in the post-Deng Xiaoping era. London: FrankCass\&Co Ltd.

Mohd Zaki Mohd Salleh (2000). Realiti satu Korea: Tamatkah edisi akhir Perang Dingin? (The reality of one Korea: Is Cold War final edition end?). Perajurit. Ogos.

Mohd Zaki Mohd Salleh (2001).China:Kuasa ketenteraan selepas Amerika Syarikat? (China: The military power after US). Perajurit. November.

Norlizah Abas (2005).Tenaga nuklear ganti minyak (Nuclear energy replace oil). Utusan Malaysia. 18 September.

Nuclear Weapons Program accessed on August 1, 2008 from http://www.fas.org/nuke/guide/japan/nuke/index.html

Nuklear untuk keamanan perlu dibenar (Nuclear for peace should be allowed).Utusan Malaysia. 28 November 2006 
Pelan tindakan tenaga baru sedang disiapkan (The action plan of new energy is being completed). Utusan Malaysia. 22 Julai 2008.

Pembinaan loji kuasa nuklear disambung semula (The construction of nuclear power lodge is continued). Utusan Malaysia.1 Februari 2001.

Peter Kien-hong Yu (2000). Mainland China's military pressures on Taiwan:An assessment. In Martin L. Laster dan Peter Kien-hong Yu (Eds.). Taiwan's security in the post-Deng Xiaoping era. London : FrankCass\&Co. Ltd.

Polis serbu ibu pejabat pemilik loji uranium (Police raids te headquaters of uranium logde owner).Utusan Malaysia.17 Disember. 1999

Ramli Dollah (2004). Sentimen anti-Amerika:Masa depan Asia Timur (Anti- US sentiment: The direction of East Asia). Jurnal Pemikir. Oktober-Disember.

Robyn Lin (2000). Taiwan and Asia-Pacific security. Dalam Martin L. Laster dan Peter Kien-hong Yu (pnyt). Taiwan's security in the post-Deng Xiaoping era. London : FrankCass\&Co Ltd.

Saiful Anwar Md Ali (2004). Kuasa tentera dan keberkesanannya (The military power and its effectiveness). Perajurit. Mac.

Sakamoto,Y.(1988). Asia : Militarization and regional conflict. Tokyo : The United Nations University.

Sarah Nadlim Rohim (2008). Tenaga nuklear penjana elektrik Malaysia masa depan (Nuclear energy generates Malaysia's electricity in future). Utusan Malaysia.14 Julai

Scalapino,R.A.(1995). Korea in the Cold War and its aftermath. Dalam East Asia in Transition: Towards new regional order. New York : M.E Sharpe.-

Senjata nuklear:Kesan letupan terhadap penduduk bandar (Nuclear weapon: Explosion effect on urban people). Perajurit. September. 1999

Senjata pemusnah dan negara paksi kejahatan? (The destruction weapon and the state of evil axis) Perajurit. Disember. 2002.

Taiwan access on August 1, 2008 daripada http://worldnuclear.org/info/inf115_taiwan.html

Tenaga nuklear:Korea Selatan bantu Indonesia (Nuclear energy: South Korea assist Indonesia).Utusan Malaysia.4 April 2006

Tragedi Hiroshima tidak berakhir (Hiroshima's tragedy is not end). Utusan Malaysia.7 Ogos 2005.

Voitti, P.R. and Kauppi, M.V.(1999). International relations theory. Boston : Allyn\&Bacon.

Wan Shawaludin Wan Hassan dan Ramli Dollah (2003). Program pembangunan senjata Korea Utara dan keselamatan rantau Asia Pasifik (North Korea's weapon development program and Asia Pacific regional security). Jurnal Pemikir. Oktober-Disember.

Zuhairi Ali (2003). Nuklear dijangka sumber utama kuasa masa depan (Nuclear is expected become a main power resources in future). Utusan Malaysia. 30 September. 